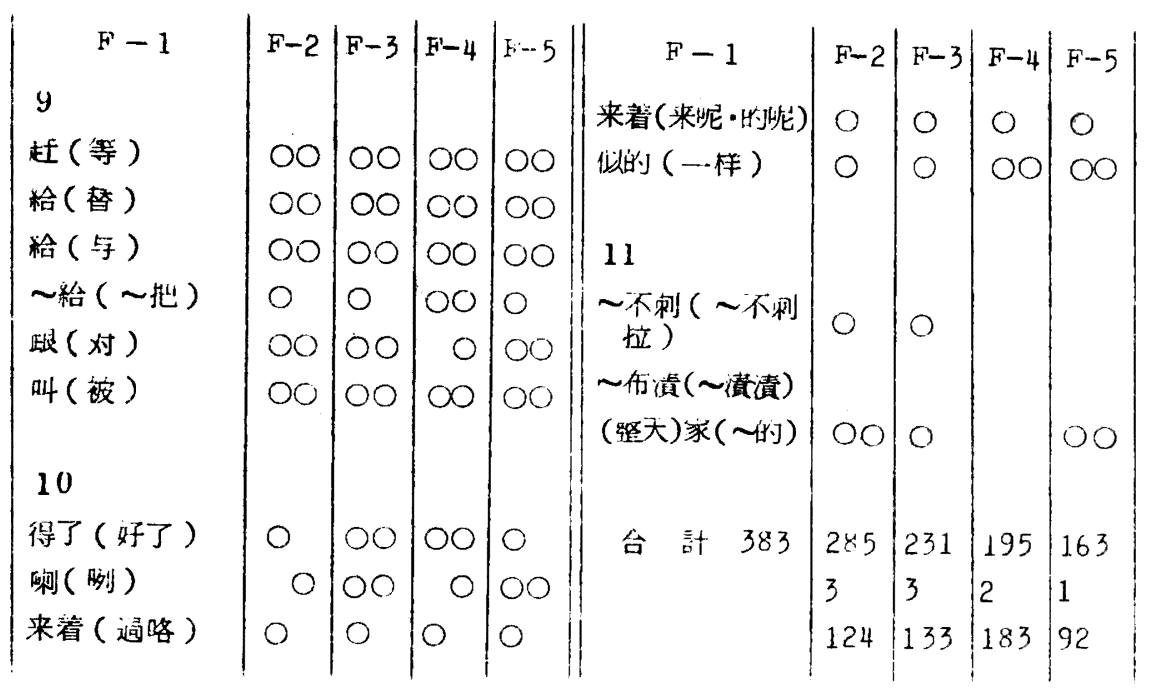

[捧]

1）表中の各語集の排列は便宜的なむのである。

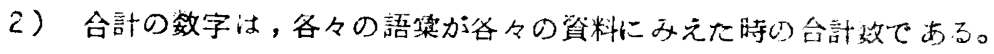

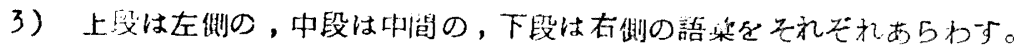

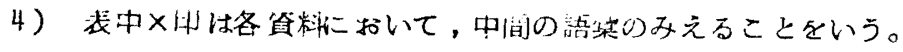

\title{
水活伝版本間にみられるコトパひ柏違
}

一金哃嘆本を中心として—

$$
\text { 大内出三即 }
$$

水澈伝には，各楎の版本が現存する が，その一つに，金㕵㗭七十回本があ る。

金㕵嘆七十回本は, 百屾本, 白二十 回本に祬いて，貲華堂から刊行せられ 萦禎末年から垷任に至る三百年むの间
に，広く愛読されてきたすのである。 このテキストは，むともと，金㕵漠 が归米の水淅伝の71回以後々切りす

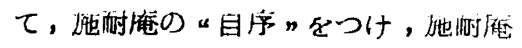
の占本と妳したすのである。设は，こ のように「水㾕伝」を胺斬したのみな 
らず，内谷にわたっても作中の人物を 自分の比語に合せて，大覑な字句の畒 きかえを行っている。

これまで，金㕵嵒 70 回本について の論及は, 主にこの㬸斬と内谷の㹮き 放元加 5 , 金聖朠の忠想的立場が追求 されている。その詊価は加んばしいあ のではないが，ただ，金告罚本のすぐ れた点として，文字の䋁一と洗練され た文字に書き改めていることがあげら れている。( 水滸。作家出悑社)しか し，金㷱唤がどのうな文字に望き改 めているのか，具体的な例示かなされ ていない。そこで，この問题について 考察を行ってみたい。

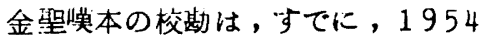
年人民文学出社 (後に，中華書局） の出版になる「水激全伝」に，郳振鏡 王利器等が行った各㮔版本の校勘記に 記載されている。ところが，周定一が 「光明日報」（1955.9.4）の紙上に 「水激全伝校勘少疑」と題し一文をの せて，この校动のもっとも大きな道漏 は「望華堂本」の校朗にみられると詊 している。したがって，「䡒華堂本 (金堮崢本)」について, 改めて校勋 そ行い誤りなきを期した。

その方法として，先ず，「天都外兵

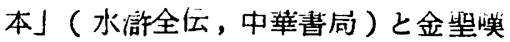
70 近本 (望華堂湶本影非) の校勋飞 行い, その両者の字可の相運を明確に ᄂ, 次に，120 回本(万有文連) の 字可も合世て比較対斯し，100回体， 120 回本, 金聖謨 70 回本の字向の相
逶を，次の順序にしたがって例示する。

I. 又字の相造

け熛準的な文字に改めたもの。

曰文字の䊺一。

巨俗字の排除。

(ㄴ) 㤐避字。

II. 語樂の相遥

$\mapsto$ 当時の白話的なものに改めたも の。

$\Leftrightarrow$ 文字の顛倒。

E一音䬣詞加5二音節詞に议めた あの。

（註）。左側の例文は「天都外臣本」 回数むこれにしたかう。 ○ー印の右は「金照嘆本」の文字。

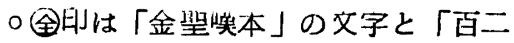
十回本」の文字が共通するすの。

\section{I. 文字の相違}

( 標準的な文字に改めたすの。 奉呈端王一奉承。(2) (全)。 我瀁到山坡下一飛贲。(2) (全。 一齊納堿一叻堿。(2)。 焰牌的按种不住一按䒬 (3)。 待平净了一立静 (3) (全, (42) 全)

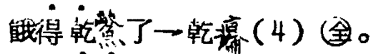
正果非凡一證果 (4)。 話休然聚 (4) 全。

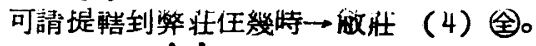
“従早晨只走到中後 $\rightarrow$ 值 (5) 全 (32) (金。 


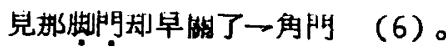

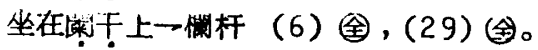

翻來愎去一得 (7) 全。

説得入意一入港 (7)。

安排案酒菓子一按 (8)。

俄須棈息着 $\rightarrow$ 精細 (8) 全。

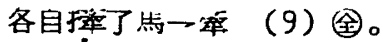

則遇推看一堆椎 (10) 公。

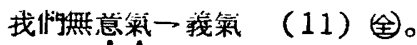

將船度過了河一渡 (12) (全。

將楊志於死风军塞監收一監守（12）

诠。

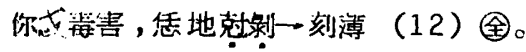
捕了草摽胃 $\rightarrow$ 草標兒 (12) 㻇。

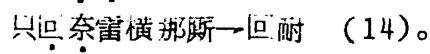

没甚分兟，一片楜笑一秙空（15）全。

路途打從造里逧過一祎過 (16) 全

(49) (全。

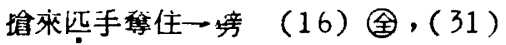

(人)。

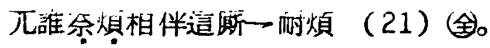

却做家札任匹裡一屋 (22) (全。

不會週全人一周全（22）囯。

便喚當地坊件作行人一地方 (22) 经。

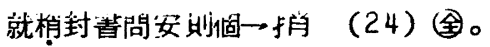

大舟指按住掩心一大指 (26)。

如此揬路一期 (29) (全。

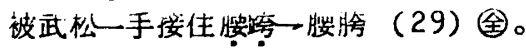
武松留住道一站 $(30)$ 全。

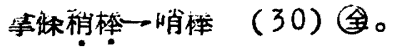

柈里裂得過一繁得逈 (31) 佺。

一保椾案纬了一楖 (31) (全, (31)

诠。

只不知你終心肯去也不?一中心（31）。

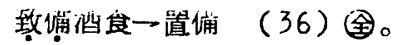

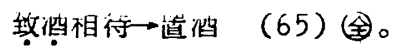

只是無人識得䊀境一路承 (41)。

监洛在此貿枈一流洛 (44)。

不如急早起能一文早 (43)。

文好刀事一極好 (44) (全。

核來柋地一湶來 (45) 图。

全付披掛了弓箭一全别（47）侄。

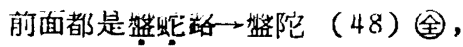

(1) 㻇。

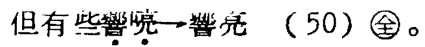

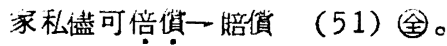

高样自下有三百梯已俥士一手下（52）

全)。

不晢埋法一艋法 (53)。

並無淫的斜心一邪心 (53) 全。

都與了型腾軍状一必勝 (55) 匋。

分投掩般出去一分頚（54）(全，(42）

웅。

小心扶侍公榇勝一伏侍 (54) 全。

相公伩間須用小心省睡一醒睡（57）

盰。

衣裳篮移一襤褗 (62)。

柴㫮幥笑不已一緮哭 (67) (全。

策人不伏一服 (69)。

賩隼的な文字に改めにものとして，以 上あげてが，この例文とみて感しるこ とは，「天都外卢本」にはかなりの

「あて字」が使われていることである。

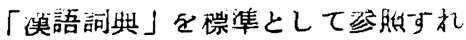
は，ほとんど「金望唤本」の文字と一 致する。だから，「金㘹英本」は，

「あて字」を垷代的な踏隼文字に敌め 
ているといえる。

又，「金望英本」が间二十回本」 の文学と約を割娄共进している等実加 5,「金望鮧本」は，字可の上で，

「四凶㓅」より，むしろ「百二十四本」 に近いことが珄解される。

$\Leftrightarrow$ 文字の繶一

「天都外能左」では，同じものと表 㟋するのに，迮口た文字が侹㸝されて いるが，金望㟋本では次の如く就一乙 ている。

撲桶地倒撞下水赛去 (19) 终

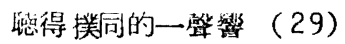

媄问的翻下水去了 (61) 得

撗咚地指下江社 (37)

把張㮌撲盌的丟下水去（65）

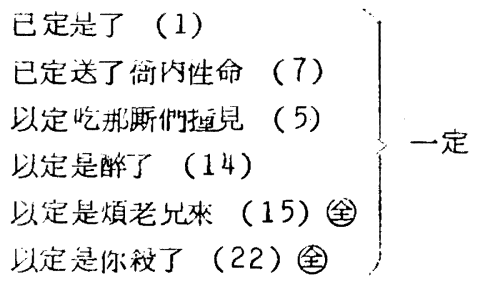

「已」と「以」はともに “斉微䫏上声” で,よく祀用される。例えば： 找等皆产失所 $\rightarrow$ 已 (19) 偣。

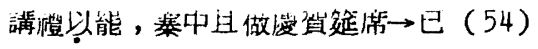
(全。 倒到三十合已上 $\rightarrow$ 以上 (68)。
具能來到暗里（31）头： 付能今日玬着一㽞 (43) (全) 付能哇火把完选取战 (48) 全 付能淔力一吹 (62)<smiles>C[13CH][13CH][13CH]</smiles>

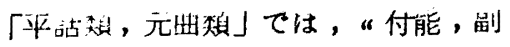
能”にも謷加礼，「金㼛栖」では， 《甫能》が䏳いられている。

高卙師表繰 (2) 全 大ㄴ.1必然黑燥

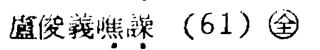

「金㼛梅」では，この外に，“蕉㕰” 等の文字が使われている。

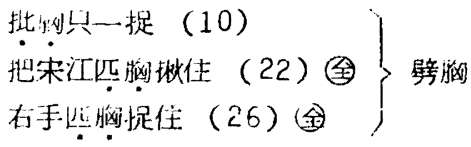

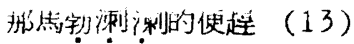

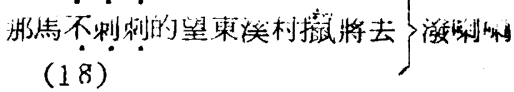

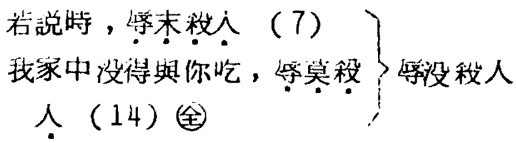

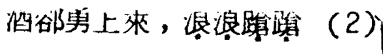

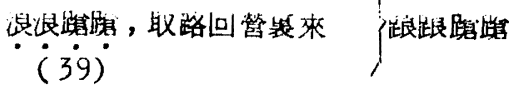

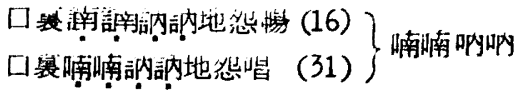




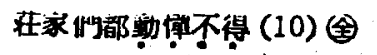

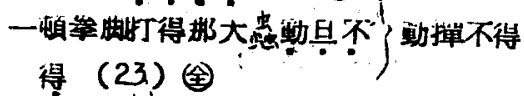

「金瓶梅」では，この外に山野啖，助 但っとすか力れている。

《庶锊, 動掉不得”の如人，「百 二十回本」ですでだ梳さされているが その他の不統一の文字か，金聖嗼によ って統一されている。

以上，統一され万方向改められて

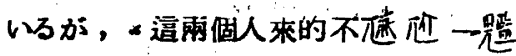

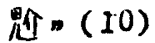

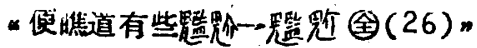
の如く，逆の方问に改めたものもあっ て，必すしむ一鿓していない。

E) 俗字の排除

俗字として次の六文字をあけたか， 「㷊䀡以来俗字譜」にみられる俗字だ けをとりあけた。

\section{盘一船}

要酎舡去一船 (11)

删時捉的舡非止千隻一船 (19)

䩑着雨集小舡一船 (19)

那大舡小舡䄪有四五十隻 (19)

证一匹

有百十还好焉一比（2）

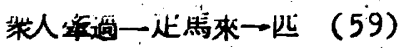

前者整我馬迟一比（68）

算 $\rightarrow$ 算

怕似不券好漠一算 (2)

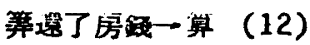

逖一逃

各目这命散了一逃 (3)

既要迯難 $\rightarrow$ 逃 (31)

咲一笑

那兵用大咲道一哭 (14)

尼盖咲道一笑 (16)

万一萬

带-拍万字㱗巾一萬

(va) 忌遊字

金望鮕本では，次の皇帝の名が避け てある。

然一炤 (朱厚照) 正德

點着將來，打一照時一炤

然挑碑偈上時一炤 (1)

照删碎後時 $\rightarrow$ 炤

看見月光微微照社身上一焒

外面火把光中，盟睍鉷叉一炤

常一皆（朱常洛）泰昌

雖然年幼, 其算道行非常一照 (1)

走了籍君，非常利害一觜 (1)

史進目此常”常與朱武等三人往來一皆管

(2)

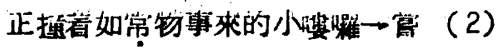

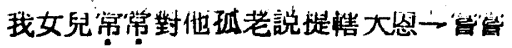
(4)

校一制(朱由枍)天啓

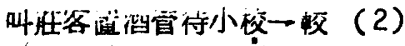




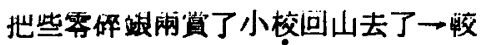

(2)

浸胢見有許多染校 $\rightarrow$ 䩙 (13)

校尉，副牌軍一蛟 (12)

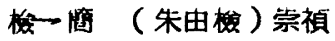

再三检轱已了 $\rightarrow$ 間 (3)

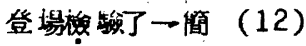

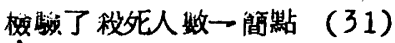

這䓢人是本找捕盗巡檢一简 (47)

由、絲 (朱由校, 朱由檢)

經由貴萿 一䋺 (2)

經由我村4過一棌（2）

等我問個來柾椂故情由一微（3）

下官問了情由一緑（3）

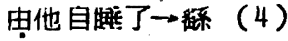

ここに挙けた忌邀字は，明末皇帝の名 であるが，金望暯は，このテキストを 改䔞与る際に，この忌避字を㺚けたあ のと. 考えられる。

「金坚唤本」は清初に刊行されたと

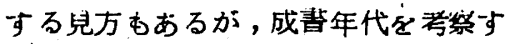
る上で，この忌避字は見逃すことはで きない。

一方, “尖説到追里一常説到道里 $n$,

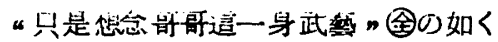
避けていない個所むみられる。

\section{II. 語集の相隼}

$\mapsto$ 当時の白話的なむのに政めたあの A.

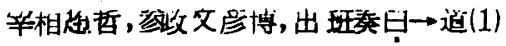

拜能起居，奏旦一道 (1)

天子回 $\rightarrow$ 道 (67)

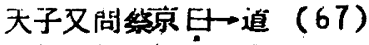

祭太師奏白一道 (67)

做損軍民多、矣 $\longrightarrow$ 甚多 (1)

回至州衙墏一到 (3) (全。

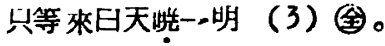

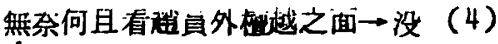

引谐家新媂居内去 $\longrightarrow$ (5)

就涪一选坐地祖合亦可一好 (9) 全。

不争我一梅打翻了他一若（9）

少刻便有船來一少頃 (11) (全。

如今只捕了白勝一揧 (18)

柴大官人之谟信一的 (19)

見他下㟫無艮子一没（20）

且只辟歕酒一柴 (21) 全。

於黒影赛㨁立起來一在 (23)。

三口兒共卓兒食一喫（24）囯。

看看天色浼了一㫮 (24)。

若如此行, 不敢苦評一苦勤（32）囯。 不知曾到也否一不 (33) 圈。

吃了早譜一啟 (34) 囯。

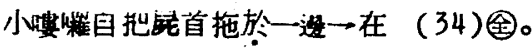
末為婏矣了 了 (35)。

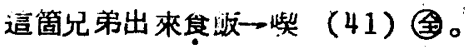

也有一年之上－多了（44）园。

怎生約会把香早兒為躆一如何 (46)。 鼠盐叫去坐于㛫林之下一在（47）图。 天使至一到 (55) 全。

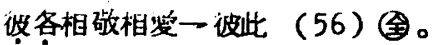

使峙造先來盗了你的甲一偷 (56)。

鼠活大怒，四㖽一知一有 $(60)$ 。

侮們乾的事使了也一完了 (62)。

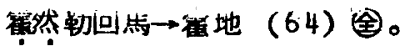


白話文の战立には文言的な榙就の大は ばな参別があった。（例えば，平話䫛） したがって後世の白話文はその影諳か ら免れることができず, 大なり小なり 文言的語策の㤨用がみられる。

一少白話文には，口䫓語を基磷とし てかこうとする然誠がはたらいている 油えに，婊垷上必要としない場合は， 文言的語果，表現加脱却しようこし た。そのあらわれが，金聖类本にもみ られる。例えば：

日一道, 矣一了, 至一到, 否一不, 小 どである。

さらに文言的語望とまでいわなくて あ，口珀語をす反映していたと思われ る語实であっても，時間がたつにつれ て，それがすでに口珀語を維貺したと みられるすのができてきた。「金旺朠

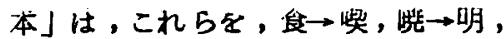
捕 $\rightarrow$ 华，盜 $\rightarrow$ 偷，则 $\rightarrow$ 只，彼各 $\rightarrow$ 诐此， 飲 $\rightarrow$ 喍，の上うに改っているが，一例 るとってさらに説閒するならば，“诐 各のは元明初にはしばしば用いられた 語であり，「王西师」「三国㴼解」な どにすみられる。しかし，これは後の 作品一例えは「拍案第奇」などになる とまったくめられなくなっている。こ のように口䫒語の死語化したものそ排 除することは，当時の讜者に語みやす くしようとしたあのであろう。

B.

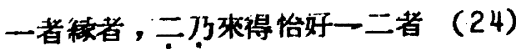

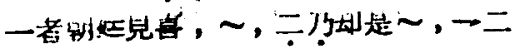

者 (40) 全。

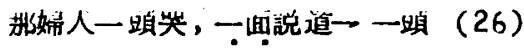

白話の裴垷中，連詞で㭔虑形式をと る場合，前俊连った文字が用いられる 傾问か，「水澈伝」や初期の占站文て はみられる。この倾问は，後になると 垷代語のように，问一文字で䊺一され るようになる。これは，このようなこ とばが一般に使用されるようになった あのと考えられる。

例えば， 《一者》で発言すれば， “二者”でうけ，“一面”, “一珀” とすれば, “一湎”，“一頻”で呼心

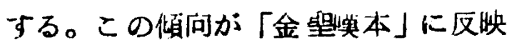
したものと考えられる。

c.

可叫林冲去替換他一教（9）因。 却叫胡正组渴一教 (26)。 叫我取銅䟠布施與他一教（46）。

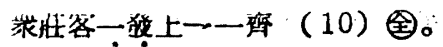

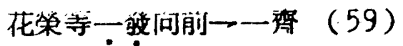

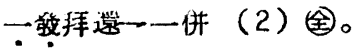

ある单語か，二つ以上の息味をむつ 場合, 刖後の成係加与，その总味か判 断されるが，これを同转語で固さかえ れば，薃解てうけずにすむわけである。 例えは, 《叫蛙, 「百回本」では

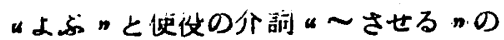
二つの用法に促っており，火の间の区 別のつさにくいものが少くない。「金

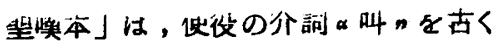


から白詁文に用いられていたい教っに

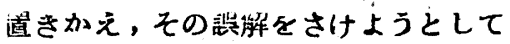
いる。

ル一蔡のについても闹にことがいえ

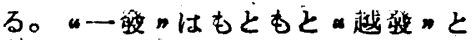

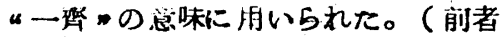

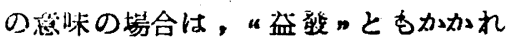
万 )。

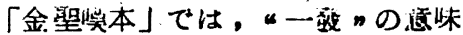

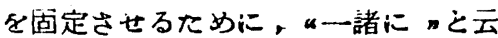

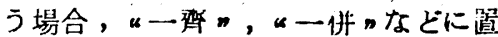

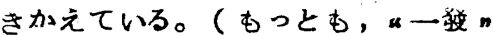
のい一齊”の意咊は，のらに少くなり

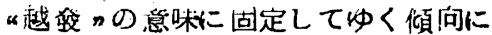
あった。例えは「紅椎要」になると， 《一乔nの意岘で用いられているばあ いは極妙く多くは 《越没意味 である）

\section{$\Leftrightarrow$ 文字の愼倒}

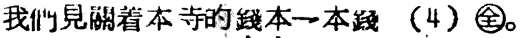

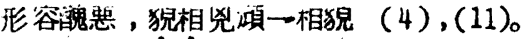

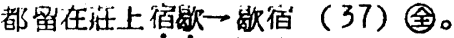

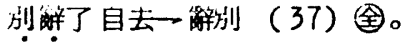

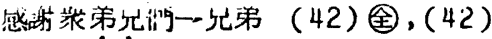
全) ( 70 ) 囯, (70) 全)。 三二十人都趧得没棓一三（4）。 䞨不過三兰里水港一二三（20）㻇。

近世になると裉台語が急に多くなっ た。その中とくに者しいすのは问我複 合語である。问諓传合語は他の語との 対立成釈とはつきりさせるために生れ たものであるが，その発生の灯期に括
いては，嗄合の峴序に安走を加いてい た。のらに，謏合語の語琎が安定し， 少多なすのは排除されるようになつた。

しかし，中荬語全体としてみるなら は，こ礼らの传势为势は，地域によっ て残情がらがっているすのあある。例 えは：

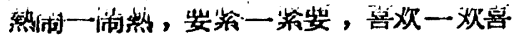
などは，左側は主として北方語系で，

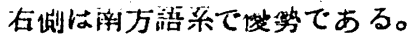

「金型舆本」で，山践本一本践，琓

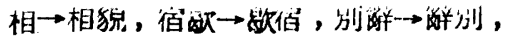
弟完 $\rightarrow$ 元第口と战められているのは， 敌めら秃た語が少くとも口犋語がっら逊 趽していたことを示すすのであろう。 また取拨の2例のような效詞の連用は 外它本ではより少い效十より多い秝， より多い效十より少い效どららの連用 あみられるが，これらが時代がさがる と肺者に䊺一される做叮が者しくなっ てきた。全呈谟が二三”をい二三”と したのはこのためであろう。甘甘に「铈 本」というをすびかたは芦と大たすか える。

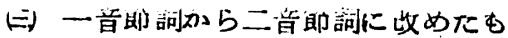

の

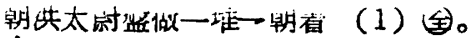
却怎地数百年冽已售找烧字任此一注定 (1) 全。

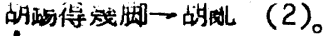
小以心下疑一矮热 (10) 全。

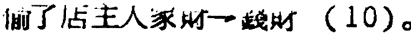

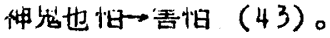




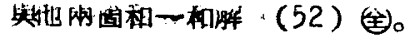

呼造妁見昰现力怯一香光（55）。

既主定了一主息 (61) (全。

中国語は一音節訶は安定が覀く，常 に二音斯詞になろうとする傾何ともっ が、介詞《朝着”を除くはかは，同我 の二音師訶として单語の安定をはかっ ている。

以上加ら，「金㕵唤本」は，全体と して珫みやすい方问に配息されている ことが判明する。

だがここで見逊せないのは，「金脰 俎本」が百二十回本」と朋字，用語

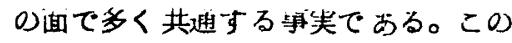
事実から，これまであけた字可の踷さ

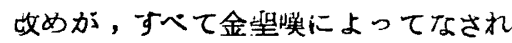
たとするのはな物疑問がのこる。

それは，「金㕵岟本」が旧来の水游 伝一「百回本」，「百二十四本」と呧 本として改㖇したものであれば，当然 その底本の文字，語篓が多くそりまま ひきつがれるからである。このことを

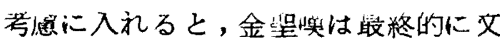
字を紌一し，洗練された文字二觜き收 めたと見る万がより妥当ではなかろう to

(こ0)惝は 1965 年度大会で発表し たあのである）

“中国諾と厸”

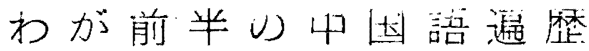

厸は約少のころ中匡で就物の望易冏 そ営む義圥のもとで䏍った。義允は仕 等の都合で東北・山東・河北・華東を 転々と升航まわった。だから私むそ0 つど義先にしたがって長居加ら消闹へ

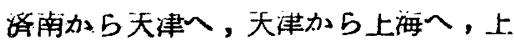
海加ら大連へとつぎつぎに居所を变え ていった。その間, 私の学柲迪いも長 香の日本人小学校と皮切りに消南での 中国人私然，天津や上海での初放・高

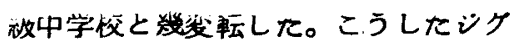

ザクのコースをたどるうちに私の中国 語は土地それでれのう礼や誂りを耑び ながら目然に培われていったようで る。

我斻は私より 20 成屯年上であり， 上海同文喆院を出ているだけに，中国 語には加なりの自信をあっていたよう である。中因人との商用文などは人の 手々かりずにけっこう目分で捕とはた していたようである。それであ会詁○ 方はあまり得手でなく，时々活に出入 